\title{
Use of bottom ash as part replacement of sand for making concrete blocks
}

\author{
Satish Sharma, VV Arora, PN Ojha, Brijesh Singh*, Vikas Patel, Adarsh Kumar NS
}

\begin{abstract}
National Council for Cement and Building Materials, India.
* Corresponding Author: brijeshsehwagiitr96@gmail.com
\end{abstract}

Received: 17-02-2021

Accepted: 19-06-2021

\begin{abstract}
Coal-based thermal power plants all over the world facing serious problems of handling and disposal of the ash produced. The productive use of coal Bottom Ash (BA) is the best way to alleviate the problems associated with its disposal. This paper covers the studies on laboratory scale evaluation of vibro compaction concrete blocks using BA I, BA II \& BA III collected from three different location of Coal Fed Thermal Power Station. In the present investigation laboratory investigation have been carried to utilize BA as part replacement of sand in concrete. This study cover manufacture of concrete blocks without flyash \& with BA using for making solid block as per specification laid down in IS:2185 using vibro compaction machine. Three different sources of BA were used in concrete mix each @ 30\%, $40 \%$ \& 50\% replacement by weight of sand were adopted in making concrete blocks. Comparative study of compressive strength of concrete at different age of curing, wet density, drying shrinkage is reported in this study. Wet density is found to be lower in blocks containing BA \& dry shrinkage values are found well within the limits of specifications. Concrete Blocks having BA @ 30\% by weight of sand are found suitable for use in the manufacture of concrete blocks.
\end{abstract}

Key words: Bottom Ash, Mix Proportion, Vibro Compaction Technique, Concrete Blocks.

\section{Introduction}

Bottom Ash (BA) is the coarser material, which drops into the bottom of the furnace in latest large thermal power plants and constitute about $20 \%$ of gross ash content of the coal fed in the boilers. It consists of noncombustible materials, and is the residual part from the incineration of household and similar waste. Raw BA is a granular material that consists of a mix of inert materials such as sand, stone, glass, porcelain, metals and ash from burnt materials. Aggarwal et al., (2007) have investigated the replacement of BA upto $50 \%$ replacement by using the superplasticizer. The study of replacement of BA is done by using high range water reducing admixture because as the replacement of fine aggregate increases the water demand rapidly which also enhances due to high specific surface area BA due to high fine content. Hence by the all mechanical properties get affected due to less cementitious material available in per cubic meter content in early age of concrete mix. Detailed studies are reported in references. BA is a combination of heavier particulate matter and molten slag, which forms on the walls and the bottom of the combustion chamber of power station boiler fired with pulverized fuel. In appearance it usually ranges from a highly verified, glossy and heavy material to a lightweight, open textured and more friable type. Sometimes it is found mixed with fly ash in stockpiles. Its precise nature depends on the boiler plant and the coal type but higher fines of fly ash in BA are generally a part of coal ash. This study utilized BA of Unchahar Super Thermal Power Plant (NTPC) currently there are two boiler systems - wet and dry.

Each system produces a uniquely different BA - wet BA and dry BA. Wet BA has a relatively low melting point and coalesces into large molten masses known as slag. Its particles usually are angular to sub angular in shape, have a smooth surface texture and looked much like crushed glass. Dry BA has quite angular particles and a highly porous surface texture, usually has the appearance similar to fine sand and lighter in weight per unit volume and colour than bottom slag (Bai and Barheer, 2001; Syahrul et al., 2010). 
The compressive strength of concrete mixes made with various percentage of washed Bottom Ash as sand replacement inclusive of control sample (fully natural sand) was determined at 3, 7, 28, and 60 days of curing (Syahrul et al., 2010). Study by Syahrul et al., (2010) indicated that the compressive strength of concrete mixes of sand replacement is much lower than control sample at all tested day. According to Purushothaman and Senthamarai (2013), BA added Concrete mixes showed enhanced compressive strength than the conventional concrete and shows uniformly higher compressive strengths at almost all ages. The ample gain in strength is thought to be due to very high pozzolanic reactivity of the two mineral admixtures silica fume and BA. Tang et al. (2013) found that the compressive and flexural strength of concrete drain with the augmentation of the BA fines at the identical curing age, particularly after 3 and 7 days. Study done by Remya Raju and Aboobacker (2014) indicated that compressive strength reduced marginally on the inclusion of BA in concrete and there was decrease in slump values of mixtures with the increase in level of replacement of sand by BA. Compressive strength, split tensile strength and flexural strength increased up to $20 \%$ replacement of BA. Based on the review of existing literature, it can be inferred that there is a potential for use of BA as replacement of fine aggregate in concrete. Compared with fly ash, BA usually has no cementitious properties, very little pozzolanic activity, coarse particle size, higher carbon content and higher water demand. Therefore, previous studies are mainly focused on using it in blocks, highway sub-base materials, structural filling materials etc. However, due to the leakage of some heavy metal elements from the above mentioned large volume construction work, only part of BA is used in these fields (Ghafoori, 1992; Ghafoori and Cai, 1998; Cheriaf et al., 1999). This has led to little recycling and large dumping of BA in landfill sites, which has gradually become a serious environmental problem in both developed and developing countries. Furthermore, owing to the construction boom in both developed and developing countries, there is a critical shortage of good quality sand in many areas throughout the world. Within the European Union, an aggregate tax has been introduced in order to conserve the natural aggregate. Therefore, there is a need for reducing the use of natural aggregate by recycling industrial by products.

Aydin and Arel (2017) investigated about the effects of high volume of fly ash in cement mix for low strength applications. Supplementary cementitious material in the mix was optimized and physical and mechanical properties were evaluated and predictive model was developed. Oruji et al. (2017) had explored the re-usability of coal bottom ash as cement replacement in mortar. The bottom ash was made pulverized and the effect on workability and setting time were studied. Kurda et al. (2018) had reviewed all earlier works done by the other researchers on the environmental impact and toxicity characteristics of recycled concrete aggregates (rca), fly ash (fa), cement production as well as their substitution aspect. The analysis with respect to abiotic depletion potential, ozone depletion potential, photochemical ozone creation, acidification potential, eutrophication potential, toxicity, leachability etc. were considered. It was revealed that environmental impact and cost of concrete reduced considerably with such incorporations, and also requirement of landfill space reduced drastically.

Bottom ash is a by-product from the combustion of coal. Recent installation of coal power plant in Norachcholai area produces bottom ash and they have no proper usage. This bottom ash has low specific gravity compared with sand. Therefore, bottom ash can be used as a raw material to manufacture light-weight masonry blocks (Abeykoon, 2012).

This paper was carried out by using BA from a thermal power plant, to replace part of sand in concrete. The main purpose was to study the possibility of using BA to make a lightweight, high performance and environmentally friendly concrete. The effect of BA on the workability, compressive strength and durability of concrete are reported in these paper so that the research going on BA found some measuring points as: 
i) The particle size distribution of the BA from the power station in is close to natural sand which makes it possible to replace the natural sand in concrete with the BA.

ii) When BA sand was used in concrete, the workability of fresh concrete improved; when used in medium to high strength concrete even for the same slump value the concrete with BA sand was easier to be cast.

iii) The replacement of sand with BA sand causes decrease of compressive strength at all ages and at all W/C. However at later ages, especially after 28 days, the compressive strength of concrete with BA sand was found to increase at a higher rate than that of the control concrete (without BA sand).

iv) The durability of concrete was detrimentally affected by increasing the replacement of natural sand with the BA sand. Further study on BA to replace the natural sand would be necessary in order to evaluate the beneficial effect of the BA sand on durability of concrete.

v) The initial results of this research suggest that BA sand can be used to replace the natural sand. Other aspects which require further investigation include the effect of ions $\&$ heavy metals present in BA on the long-term performance of concrete.

\section{Materials used}

The physical and chemical characteristics of 43 grade Ordinary Portland Cement is given in Table-1. The results of cement are satisfying the codal provision laid down in IS: 269. Coarse aggregates with a maximum nominal size of $10 \mathrm{~mm}$ and natural riverbed sand confirming to Zone II as per Indian Standard IS: 383-2016 was used as fine aggregate for concrete (Table 2 and Table 3). The physical characteristics of BA used in the study is given in Table-4. Different tests (Physical \& Chemical) were carried out on the bottom ash collected from Coal Fed Thermal Power Plant of NTPC Unchahar.

Table 1. Physical and chemical characteristics of 43 grade ordinary Portland cement

\begin{tabular}{|c|c|c|}
\hline Sl. No. & Test & Results Obtained \\
\hline 1 & Blain's Fineness, $\mathrm{m}^{2} / \mathrm{kg}$ & 299.5 \\
\hline 2 & Setting Time, minutes: Initial \& Final & $126 \& 206$ \\
\hline 3 & $\begin{array}{c}\text { Soundness : Lechatlier Exp., mm } \\
\text { Autoclave Exp., \% }\end{array}$ & $\begin{array}{l}1.00 \\
0.082\end{array}$ \\
\hline 4 & $\begin{array}{l}\text { Compressive Strength, } \mathrm{N} / \mathrm{mm}^{2} \\
3 \text { days } \\
7 \text { days } \\
28 \text { days }\end{array}$ & $\begin{array}{l}32 \\
40 \\
48\end{array}$ \\
\hline 5 & $\begin{array}{l}\text { Chemical Analysis, \%: } \\
\text { Loss on Ignition } \\
\text { Silica }\left(\mathrm{SiO}_{2}\right) \\
\text { Iron Oxide }\left(\mathrm{Fe}_{2} \mathrm{O}_{3}\right) \\
\text { Aluminium }\left(\mathrm{Al}_{2} \mathrm{O}_{3}\right) \\
\text { Calcium Oxide }(\mathrm{CaO}) \\
\text { Sulphate }\left(\mathrm{SO}_{3}\right) \\
\text { Magnesium Oxide }(\mathrm{MgO})\end{array}$ & $\begin{array}{c}2.05 \\
22.45 \\
5.18 \\
5.44 \\
59.69 \\
1.26 \\
2.80\end{array}$ \\
\hline 6 & $\begin{array}{l}\text { Alkalies (\%): } \\
\mathrm{Na}_{2} \mathrm{O} \& \mathrm{~K}_{2} \mathrm{O}\end{array}$ & $0.57 \& 0.36$ \\
\hline
\end{tabular}


Table 2. Physical characteristics of fine aggregate

\begin{tabular}{|c|c|c|}
\hline Sl. No. & Parameter/Tests & Test Value \\
\hline 1 & Silt content & $2.33 \%$ \\
\hline 2 & Clay lumps & Nil \\
\hline 3 & Organic impurities & Nil \\
\hline 4 & Soundness & $2.27 \%$ \\
\hline 5 & Sp. Gravity & $0.90 \%$ \\
\hline 6 & Water absorption & Percent Passing \\
\hline 7 & Sieve Size analysis & 100.00 \\
& $10 \mathrm{~mm}$ & 90.60 \\
& $4.75 \mathrm{~mm}$ & 78.65 \\
& $2.36 \mathrm{~mm}$ & 54.60 \\
& $1.18 \mathrm{~mm}$ & 40.15 \\
& $600 \mathrm{micron}$ & 23.15 \\
& $300 \mathrm{micron}$ & 10.35 \\
& 150 micron & $\mathrm{Nil}$ \\
& Pan & \\
& \multicolumn{2}{|c|}{} \\
\end{tabular}

Table 3. Physical characteristics of coarse aggregate

\begin{tabular}{|c|c|c|}
\hline Sl No. & Parameter/tests & Test Results \\
\hline 1 & Specific gravity & 2.69 \\
\hline 2 & Water absorption & $0.40 \%$ \\
\hline 3 & Crushing value & $24.73 \%$ \\
\hline 4 & Impact value & 18.34 \\
\hline 5 & Abrasion value & 19.04 \\
\hline 6 & Soundness & $0.30 \%$ \\
\hline 7 & Flakiness Index (<10 mm) & $29 \%$ \\
\hline 8 & Elongation Index $(<10 \mathrm{~mm})$ & $32.76 \%$ \\
\hline 9 & Sieve analysis & Percent Passing \\
\hline \multirow{3}{*}{} & $10 \mathrm{~mm}$ & $96.06 \%$ \\
\cline { 2 - 3 } & $4.75 \mathrm{~mm}$ & $16.40 \%$ \\
\cline { 2 - 3 } & $2.36 \mathrm{~mm}$ & Nil \\
\hline
\end{tabular}

Figure- 1 shows the gradation curve of BA I, II \& III and fine aggregate. All three type of BA are found to be very finer than the sand grading. In all three types the $600 \mu$ and lower particle size greater than the usually present in coarse sand used in this study. Also compare with the grading of plaster sand \& masonry sand the grading of BA is not comparable because BA has very fine particle $600 \mu$ and down size. BA and boiler slag are made essentially out of silica, alumina, and iron, with smaller percentages of calcium, magnesium, sulfates, and other compounds. The composition of the above particles is controlled principally by the source of the coal and not by the type of furnace. BA or boiler slag derived from lignite or sub-bituminous coals have a higher percentage of calcium than that from anthracite or bituminous coals. Due to the salt content and, in some cases, the low $\mathrm{pH}$ of $\mathrm{BA}$ and boiler slag, these materials could display corrosive properties. When BA or boiler slag is used in an embankment, backfill, sub-base, or even possibly in a base course, the potential for corrosion of metal structures that may come in contact with the material is of high concern and should be investigated prior to use so that it does not pose any problem. Water meeting the requirements of Indian Standard IS: 456-2000 has been used. 
Table 4. Characteristics of bottom ash (BA)

\begin{tabular}{|c|c|c|c|c|}
\hline Sl No. & Test & BA I & BA II & BA III \\
\hline \multicolumn{5}{|c|}{ Physical Test } \\
\hline 1 & Water absorption (\%) & 2.90 & 3.80 & 4.20 \\
\hline 2 & Sp. gravity & 2.11 & 2.12 & 2.19 \\
\hline 3 & Lime reactivity $\left(\mathrm{Kg} / \mathrm{cm}^{2}\right)$ & 19.2 & 16.0 & 21.2 \\
\hline \multirow[t]{8}{*}{4} & Sieve analysis & & & \\
\hline & 4.75 & 100.00 & 100.00 & 100.00 \\
\hline & 2.36 & 100.00 & 98.75 & 99.00 \\
\hline & 1.18 & 95.70 & 94.62 & 98.00 \\
\hline & 600micron & 92.40 & 90.12 & 95.63 \\
\hline & 300micron & 72.50 & 66.74 & 82.00 \\
\hline & 150micron & 41.10 & 33.61 & 46.00 \\
\hline & Pan & 0.00 & 0.00 & 0.00 \\
\hline \multicolumn{5}{|c|}{ Chemical Test } \\
\hline 1 & Loss on Ignition & 2.80 & 1.76 & 2.63 \\
\hline 2 & Silica (SiO2) & 62.45 & 58.75 & 58.98 \\
\hline 3 & Iron oxide & 7.16 & 14.41 & 7.81 \\
\hline 4 & Aluminum oxide & 22.17 & 19.69 & 24.81 \\
\hline 5 & Calcium oxide $(\mathrm{CaO})$ & 1.34 & 1.28 & 1.29 \\
\hline 6 & Magnesium oxide $(\mathrm{MgO})$ & 0.48 & 0.58 & 0.46 \\
\hline \multicolumn{5}{|c|}{$\begin{array}{l}\text { BA II=Bottom Ash Stake II } \\
\text { BA III=Bottom Ash Stake III }\end{array}$} \\
\hline
\end{tabular}

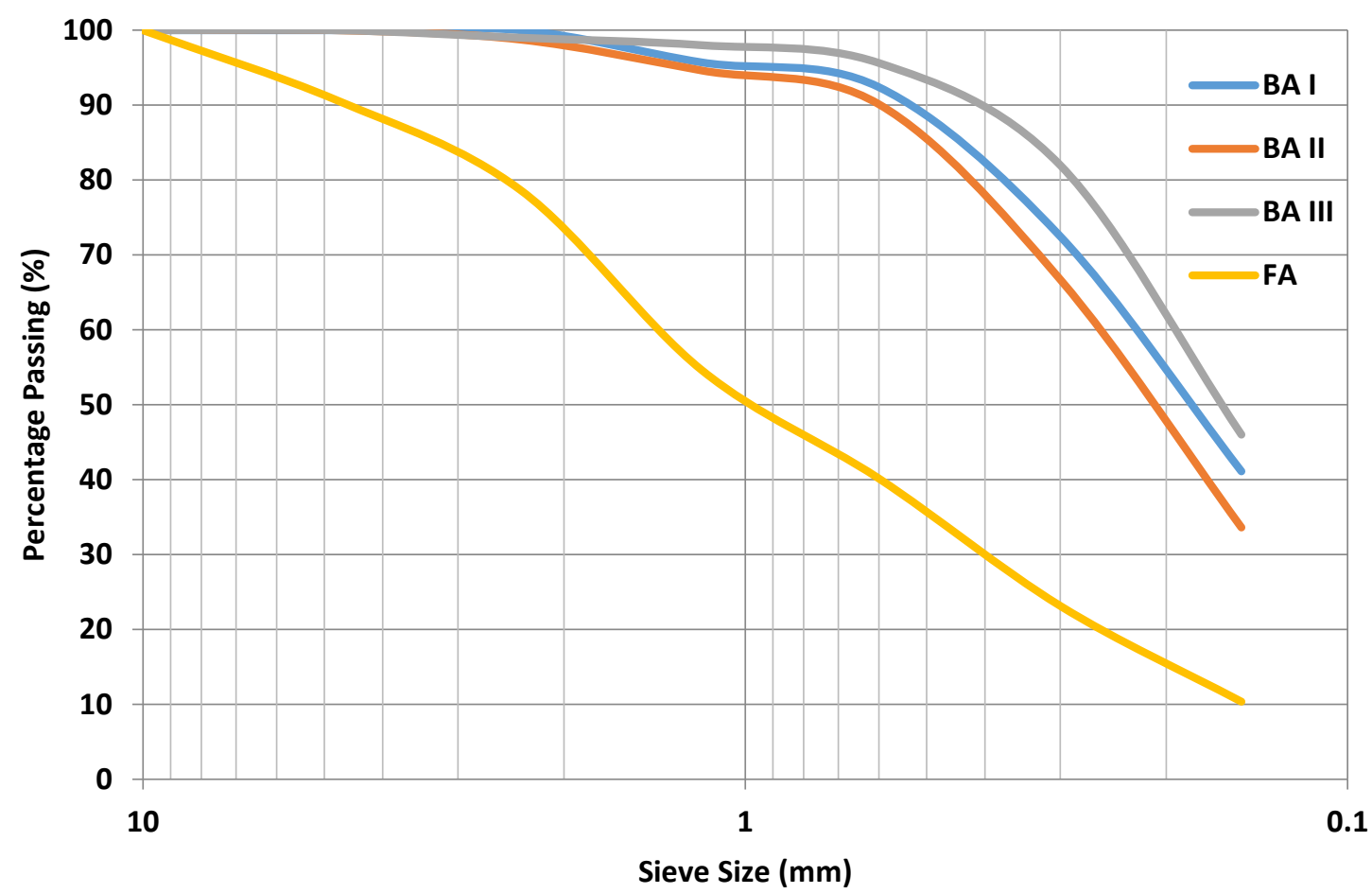

Fig. 1. Gradation Curve for Fine Aggregate and Bottom Ash: BA-I, II \& B-III 


\section{Selection of Mix Proportion with Different W/C Ratio}

Different trial mixes (Table-5) were made using:

1. Direct replacement of bottom ash (by weight of coarse sand in percentage)

2. Replacement in equal volume of coarse sand and bottom ash

Table 5. Matrix for Selection of $\mathrm{W} / \mathrm{C}$ ratio \& Ratio of concrete mix

\begin{tabular}{|c|c|c|c|}
\hline \multirow{2}{*}{$\begin{array}{c}\text { W/C } \\
\text { Ratio }\end{array}$} & \multicolumn{3}{|c|}{ Ratio of Cement : Sand : Aggregate } \\
\hline & $1: 3: 6$ & $1: 3.125: 6.25$ & $1: 2.5: 5$ \\
\hline 0.45 & $\begin{array}{c}\text { Seems more water } \\
\text { required for casting to } \\
\text { block in vibro machine }\end{array}$ & $\begin{array}{c}\text { Blocks but did not give clear } \\
\text { dimensions, so the mix was } \\
\text { rejected }\end{array}$ & $\begin{array}{c}\text { Block successfully but } \\
\text { did not give cost- } \\
\text { effective option }\end{array}$ \\
\hline 0.50 & $\begin{array}{c}\text { Less sand \& less water } \\
\text { content observed }\end{array}$ & $\begin{array}{c}\text { Block caste successfully } \\
\text { with economy in view }\end{array}$ & Block successfully \\
\hline 0.55 & $\begin{array}{c}\text { Less sand content } \\
\text { observed }\end{array}$ & $\begin{array}{c}\text { Block caste successfully for } \\
\text { study of required properties }\end{array}$ & $\begin{array}{c}\text { Block caste successfully } \\
\text { but higher cement } \\
\text { content did not allow } \\
\text { further work }\end{array}$ \\
\hline
\end{tabular}

Hence, ratio of 1:3.125:6.25 is selected for mix proportion and $\mathbf{W} / \mathbf{C}$ ratio $\mathbf{0 . 5 0}$ is selected on the basis of strength. Method of mix design by replacing the ratio of specific gravity was found suitable than direct replacement of sand, but fines of BA still gave higher specific surface area thus increasing the water demand. Water demand also was found higher due to higher water absorption by BA. Optimised mix proportion for required strength without using BA (Table-6):

Table 6. Optimised mix proportion for required strength without using Bottom Ash (BA)

\begin{tabular}{|c|c|c|c|c|}
\hline $\begin{array}{c}\text { Ingredient in } \\
\text { Mix }\end{array}$ & Cement & Coarse Sand-Natural & $\begin{array}{c}10 \mathrm{~mm} \text { Aggregate- } \\
\text { Crushed Stone }\end{array}$ & Free W/C \\
\hline Mix proportion & 1 Part & 3.125 Part & 6.25 Part & 0.5 \\
\hline
\end{tabular}

Batch Mix Proportion used in Laboratory $(\mathrm{W} / \mathrm{C}=0.5 \%)$ using BA to replace the sand content given in Table-7:

Table 7. Mix proportions of concrete blocks

\begin{tabular}{|c|c|c|c|c|}
\hline \multirow{2}{*}{ Ingredient } & \multirow{2}{*}{$\begin{array}{c}\text { Mix } \\
\text { Proportions } \\
\text { Without } \\
\text { Bottom Ash }\end{array}$} & $\begin{array}{c}\text { Meplacement as } \\
\text { Fine Aggregate }\end{array}$ & $\begin{array}{c}\text { Meplacement as } \\
\text { Fine Aggregate }\end{array}$ & $\begin{array}{c}\text { Replacement as } \\
\text { Fine Aggregate }\end{array}$ \\
\cline { 3 - 5 } & Quantity (Kg) & Quantity (Kg) & Quantity (Kg) & Quantity (Kg) \\
\hline Cement, Kg & 188.24 & 181.17 & 177.5 & 170.8 \\
\hline Coarse Sand, Kg/cum & 0.37 & 0.25 & 0.21 & 0.17 \\
\hline Bottom Ash, kg/cum & Nil & 135.16 & 176.77 & 212.64 \\
\hline $\begin{array}{c}\text { Coarse Aggregate } \\
\text { (<10mm) }\end{array}$ & 0.74 & 0.57 & 0.55 & 0.53 \\
\hline Water, Ltr & 94.11 & 90.5 & 90.5 & 85.4 \\
\hline $\begin{array}{c}\text { Wet Density of } \\
\text { Concrete, Kg/cum }\end{array}$ & 2000 & 1925 & 1886 & 1815 \\
\hline $\begin{array}{c}\text { Weight of Concrete } \\
\text { Block, Kg (390x175x90 } \\
\text { mm) }\end{array}$ & 12.28 & 11.82 & 11.57 & 11.14 \\
\hline
\end{tabular}

The study indicated that for various percentages of replacement of sand with bottom ash the workability of concrete decreased with the increase in bottom ash content. The workability of the concrete was correlated to its slump value and it was observed that up to $50 \%$ replacement 
of Coal Bottom ash, the slump was found to be in the range $60-150 \mathrm{~mm}$. The decrease in workability can be attributed to the fact that the Coal Bottom Ash is irregular in shape, vesicular in texture and porous such that friction between particles is high. Thus, with increasing Coal Bottom Ash content, there is an increase in water demand to achieve similar workability as for the control mix.

\subsection{Procedure using Vibro Compaction Technique for Making Concrete Blocks}

Vibro Compaction method is probably the most extensively used technique for compacting concrete. In this method, internal friction between aggregate particles is eliminated for a short time and concrete mixtures behave like liquid and gravitational force will come into effect. Following procedure was adopted in making concrete blocks:

Step I Take all the material as per batch given in Table-7.

Step II Make a dummy trial batch (around 10\% quantity with same proportion) and remove from concrete mixture so that a thin layer of mix can adhere with surface of mixture for simulating the continuous batch mix.

Step III Now add all the quantity (excepts aggregate) and mix it for 60 seconds. Now add aggregate and mix the total batch for 120 seconds.

Step IV Now remove the batch to a non-water absorbing surface and fill the mould to cast the block in vibro compaction machine.

Step V When blocks are filled to total mould volume, vibrate for 60 seconds and remove from mould.

Step VI Lift the caste block for drying (in shaded area) for 24 hours.

Step VII Cure the block 3 day with gunny bags/in moist environment and the cure 7 day in submersed condition \& there after cure the bock stacks in air by sprinkling water

\section{Results \& Discussion}

\subsection{Compressive Strength}

The compressive strength of concrete blocks made with BA I, II and III are given in Table 8. From this table it can be concluded that $30 \%$ replacement of BA I, II \& III gives results of compressive strength almost similar to control concrete.

Table 8. Compressive strength of concrete blocks obtained.

\begin{tabular}{|c|c|c|c|c|c|}
\hline \multicolumn{3}{|c|}{$\begin{array}{c}\text { Compressive Strength (N/mm } \\
\text { Different Age (Day) }\end{array}$} & Control Mix & \multicolumn{2}{|c|}{$\begin{array}{c}\text { Percentage Replacement in the Ratio } \\
\text { of Specific of BA/Sand }\end{array}$} \\
\cline { 4 - 6 } & & & $\mathbf{3 0 \%}$ & $\mathbf{4 0 \%}$ & $\mathbf{5 0 \%}$ \\
\hline $\begin{array}{c}\text { Using BA-I for NTPC, } \\
\text { Unchahar (Source I) }\end{array}$ & 3 & 7.01 & 6.89 & 2.34 & 1.92 \\
\cline { 2 - 6 } & 7 & 10.02 & 9.88 & 2.27 & 2.11 \\
\cline { 2 - 6 } & 28 & 11.24 & 10.67 & 3.47 & 3.50 \\
\cline { 2 - 6 } & 56 & 11.74 & 11.25 & 4.12 & 3.85 \\
\hline Using BA-II for NTPC, & 3 & 7.01 & 6.85 & 1.57 & 0.99 \\
\cline { 2 - 6 } Unchahar (Source II) & 7 & 10.02 & 9.96 & 2.89 & 2.53 \\
\cline { 2 - 6 } & 28 & 11.24 & 10.86 & 4.02 & 3.38 \\
\cline { 2 - 6 } & 56 & 11.74 & 11.12 & 4.44 & 3.69 \\
\hline Using BA-III for NTPC, & 3 & 7.01 & 6.95 & 1.35 & 0.96 \\
\cline { 2 - 6 } Unchahar (Source III) & 7 & 10.02 & 10.12 & 2.47 & 2.46 \\
\cline { 2 - 6 } & 28 & 11.24 & 10.50 & 4.26 & 3.98 \\
\cline { 2 - 6 } & 56 & 11.74 & 10.76 & 4.36 & 4.23 \\
\hline
\end{tabular}




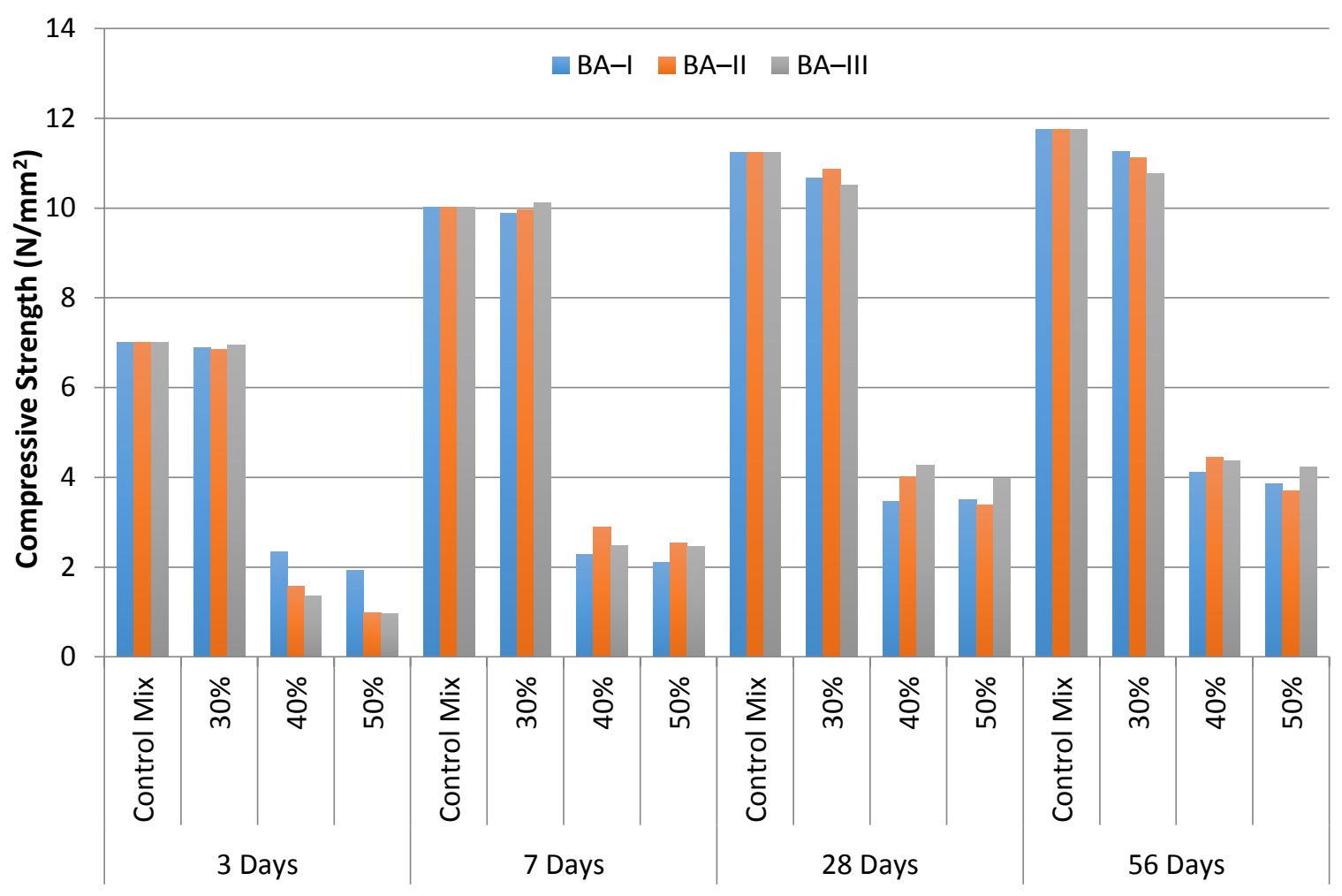

Percentage replacement at different ages

Fig. 2. Compressive Strength of control mix and mix with different replacement percentages of Bottom Ash at different ages

From Figure- 2 above it can be see that the compressive strength of concrete blocks using BA decreases at early age but slightly increases further at 56 day \& 90 day. The results of higher replacement of $\mathrm{BA}$ beyond $30 \%$ indicates that there is further no substantial increase in compressive strength.

\subsection{Density \& Drying Shrinkage of Concrete Block}

The density of concrete block decreases with increase in percentage of BA (Table 9 \& Figure-3). The density of concrete block also increases when the finer particle from BA is removed. Drying shrinkage is found to be slightly higher in BA samples prepared by cutting the concrete blocks samples from concrete blocks with $30 \%, 40 \%$ \& $50 \%$ of BA as compared to control concrete blocks without BA (Tabel-10 and Figure-4). The density of concrete block can be increased by using state-of-the-art block making machine or use of Superplasticiser (High range water reducer agent) which in turn will improve the compressive strength and density.

Table 9. Density of concrete blocks (in $\mathrm{Kg} / \mathrm{m}^{3}$ )

\begin{tabular}{|c|c|c|c|c|}
\hline \multirow{2}{*}{ Bottom Ash } & \multicolumn{4}{|c|}{ Replacement Percentage } \\
\cline { 2 - 5 } & $30 \%$ & $40 \%$ & $50 \%$ & Control Mix \\
\hline BA-I & 1925 & 1886 & 1815 & 2000 \\
\hline BA-II & 1915 & 1868 & 1794 & 2000 \\
\hline BA-III & 1754 & 1854 & 1787 & 2000 \\
\hline
\end{tabular}




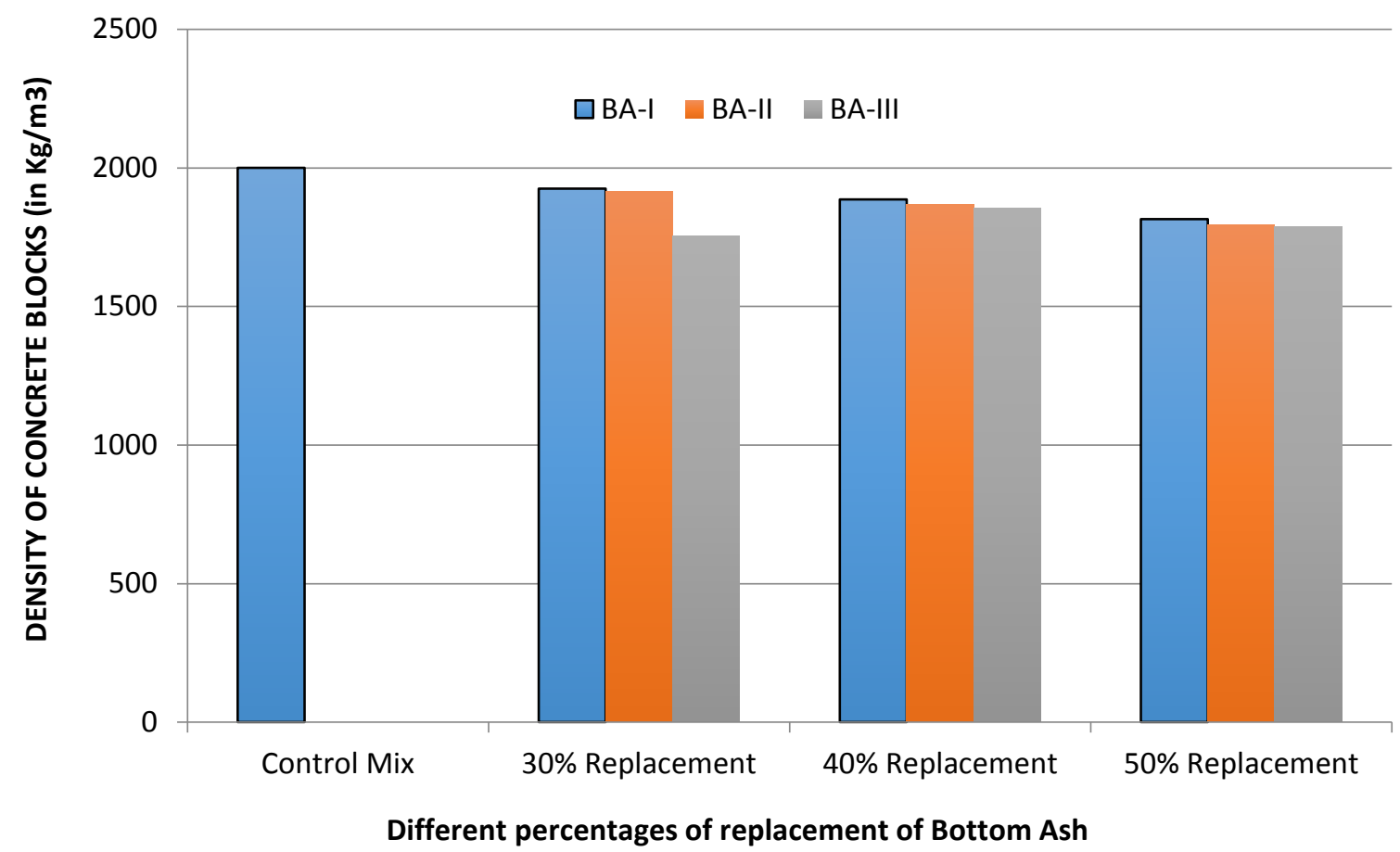

Fig. 3. Density of control mix and mix with different replacement percentages of Bottom Ash at different ages

Table 10. Drying shrinkage of concrete blocks (\%)

\begin{tabular}{|c|c|c|c|c|}
\hline \multirow{2}{*}{ Bottom Ash } & \multicolumn{4}{|c|}{ Replacement Percentage } \\
\cline { 2 - 5 } & $30 \%$ & $40 \%$ & $50 \%$ & Control Mix \\
\hline BA-I & 0.0692 & 0.0692 & 0.0817 & $0.0413 \%$ \\
\hline BA-II & 0.0712 & 0.0714 & 0.0720 & $0.0413 \%$ \\
\hline BA-III & 0.0746 & 0.0770 & 0.0890 & $0.0413 \%$ \\
\hline
\end{tabular}

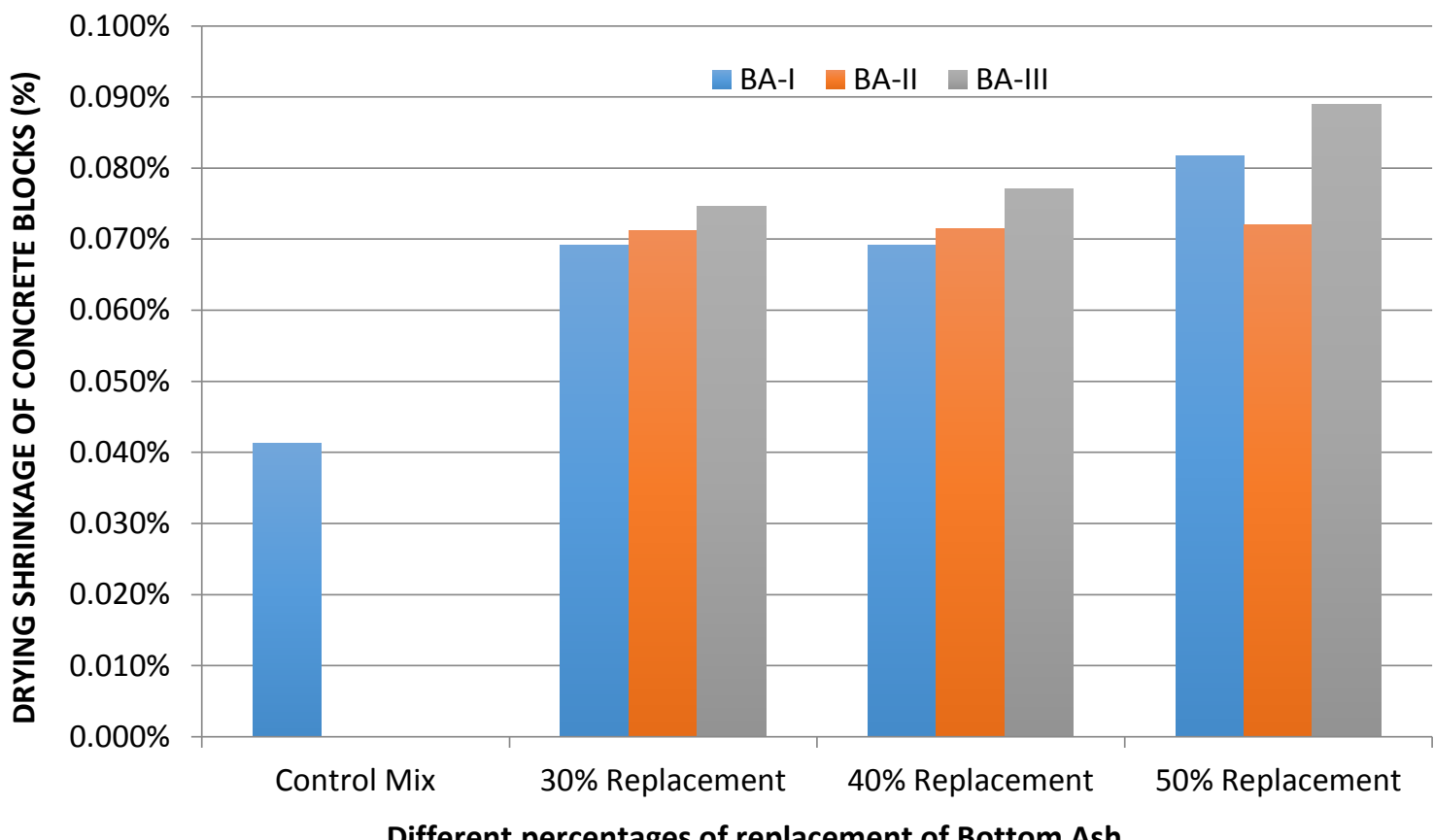

Fig. 4. Drying Shrinkage of control mix and mix with different replacement percentages of Bottom Ash at different ages 
Due to lower density \& higher water absorption higher percentage of fines in all the three sources of BA, the coal BA as alternative to sand is not found to be techno-economically viable alternative. It can be said that replacement of sand with BA up to $30 \%$ is technically suitable/feasible and meets the requirement of IS-2185. Although using $40 \%$ \& $50 \%$ of BA from the three sources the compressive strength obtained in concrete blocks is lower than $10 \mathrm{~N} / \mathrm{mm}^{2}$ but certainly by use of vibro-compaction technique, all the concrete blocks are found technically suitable as far as the requirement of meeting the compressive strength as laid down in IS: 2185 is concerned. Higher compacting effort using of modern machinery with use of Superplasticiser will definitely improve the strength \& density of concrete blocks

\section{Conclusion and Recommendations}

Some of the properties of BA such a higher fine particles and higher water absorption are in general found economically unviable for replacing sand due to the decrease in strength associated with the increased fine content in the concrete.

- $\quad$ Density of concrete blocks is also found lower using 30\%, 40\% \& 50\% BA as compared to the concrete blocks without BA irrespective of the source of BA.

- Drying shrinkage is found to be slightly higher in BA samples prepared by cutting the concrete blocks samples from concrete blocks with $30 \%, 40 \%$ \& $50 \%$ of BA as compared to control concrete blocks without BA.

- $\quad$ Due to lower density \& higher drying shrinkage values, concrete blocks, corresponding compressive strength of concrete blocks using 30\%, 40\% \& 50\% is also found lower at all ages i.e. 3, 7, 28, $56 \& 90$ day. This is true for all the three sources of fly ash investigated. $30 \%$ replacement of BA I, II \& III gives results of compressive strength almost similar to control concrete.

- $\quad$ Due to lower density \& higher water absorption higher percentage of fines in all the three sources of BA, the coal BA as alternative to sand is not found to be technoeconomically viable alternative. It can be said that replacement of sand with BA upto $30 \%$ is technically suitable/feasible and meets the requirement of IS-2185. Although using $40 \%$ \& $50 \%$ of BA from the three sources the compressive strength obtained in concrete blocks is lower than $10 \mathrm{~N} / \mathrm{mm}^{2}$ but certainly by use of vibro compaction technique, all the concrete blocks are found technically suitable as far as the requirement of meeting the compressive strength as laid down in IS: 2185 is concerned.

To improve the quality of BA to make the same as techno economically viable alternative, sieved BA after removed of after $150 \mu$ and 300 down size shall be preferable for usage in concrete blocks.

- $\quad$ From the grading it is seen that the BA can also be used in mortar making for use in masonry and plastering work as the grading of bottom is found suitable for these works. The grading requirement of fine sand for use in mortar making and after partly removal of $150 \mu \& 300 \mu$ sieve.

\section{References}

Abeykoon, A. J. M. S. S., Anthony, C. S. K. R., \& De Silva, G. H. M. J. S. (2012). Bottom ash as replacement of sand for manufacturing masonry blocks, Conference, Sri Lanka.

Aggarwal P., Aggarwal Y., \& Gupta S.M. (2007). Effect of Bottom Ash as Replacement of Fine Aggregates in Concrete. Asian Journal of Civil Engineering (Building and Housing), 8(1), 49-62. 
Aydin, E., \& Arel, H. Ş. (2017). Characterization of high-volume fly-ash cement pastes for sustainable construction applications. Construction and Building Materials, 157, 96-107.

Bai Y., \& Barheer P A M. (2001). Influence of Furnace Ash on Workability, Compressive Strength and Durability of Concrete. Seventh CANMET/ACI International Conference on Fly Ash, Silica Fume, Slug and Natural Pozzolana in Concrete, Chennai (Madras), India.

Cheriaf, M., Rocha, J. C., \& Pera, J. (1999). Pozzolanic properties of pulverized coal combustion bottom ash. Cement and concrete research, 29(9), 1387-1391.

Ghafoori, N. (1992). Utilisation of Type C Bottom Ash in Cement Based Concrete Mixtures. Annual Report, Material Technology Center, Southern Illinois University at Carbondale, 55-76.

Ghafoori, N., \& Cai, Y. (1998). Laboratory Made Roller Compacted Concretes Containing Dry Bottom Ash: Part I - Mechanical Properties. ACI Materials Journal, 95 (2), 121-130

Kurda, R., Silvestre, J. D., \& de Brito, J. (2018). Toxicity and environmental and economic performance of fly ash and recycled concrete aggregates use in concrete: A review. Heliyon, 4(4), e00611.

Oruji, S., Brake, N. A., Nalluri, L., \& Guduru, R. K. (2017). Strength activity and microstructure of blended ultra-fine coal bottom ash-cement mortar. Construction and Building Materials, $153,317-326$.

Purushothaman, M., \& Senthamarai, R. M. (2013). Strength properties of high performance concrete using bottom ash as fine aggregate. International Journal of Civil, 2(3), 35-40.

Remya Raju, M. M. P., \& Aboobacker, K. A. (2014). Strength performance of concrete using bottom ash as fine aggregate. International Journal of Research in Engineering \& Technology, 2(9), 111-122.

Syahrul, M. S. H. M., Muftah, F., \& Muda, Z. (2010). The properties of special concrete using washed bottom ash (WBA) as partial sand replacement. International Journal of Sustainable Construction Engineering and Technology, 1(2), 65-76.

Tang, P., Yu, Q. L., Yu, R., \& Brouwers, H. J. H. (2013, October). The application of MSWI bottom ash fines in high performance concrete. In Proceedings of the 1st International Conference on the Chemistry of Construction Materials, Berlin, Germany, pp. 435-438. 